\title{
Physiological Race Characterization of Phytophthora capsici Isolates from Several Host Plant Species in Brazil Using New Mexico Recombinant Inbred Lines of Capsicum annuum at Two Inoculum Levels
}

\author{
Cláudia S. da Costa Ribeiro ${ }^{1}$ and Paul W. Bosland ${ }^{2,3}$ \\ Department of Plant and Environmental Science, New Mexico State University, Las Cruces, NM \\ 88003-8003
}

\begin{abstract}
AdDitional INDEX wORDs. disease resistance, pepper, phytophthora root rot, race-specific resistance, RILs, screening method
Abstract. Phytophthora blight, caused by Phytophthora capsici, is one of the most destructive diseases worldwide that affects Capsicum pepper. Attempts to provide universally resistant cultivars has been unsuccessful, which may be the result of the use of different resistance sources, pathotypes, or races of $P$. capsici isolates and screening techniques. The screening method used at Embrapa Vegetables in Brazil to detect resistance to $P$. capsici in Capsicum was compared with the screening method used at New Mexico State University. Both screening methods produced similar and consistent results when a range of $\boldsymbol{P}$. capsici isolates were used. It was concluded that either method can successfully differentiate resistant and susceptible individuals. In addition, $20 P$. capsici isolates from Brazil were characterized for virulence using a subset of 26 New Mexico recombinant inbred lines of pepper (Capsicum annuum). Within the $P$. capsici populations from Brazil, eight new physiological races for the root rot disease syndrome were identified. A total of nine isolates were pathogenic only on the susceptible control, 'Camelot'. The ability to identify physiological races of $\boldsymbol{P}$. capsici occurring in Brazil allows for a better understanding about race-specific resistance leading to improved approaches in breeding for durable resistant cultivars.
\end{abstract}

The oomycete Phytophthora capsici is a soilborne pathogen that causes severe and even complete yield loss in pepper worldwide (Lamour et al., 2012). In Brazil, pepper root rot caused by P. capsici was observed for the first time in 1952 in São Paulo State (Amaral, 1952) and since then has been identified in more areas of Brazil (Lima, 2006). This pathogen causes several disease syndromes on pepper plants such as root rot, stem blight, foliar blight, and fruit rot (Candole et al., 2010; Oelke et al., 2003; Sy et al., 2005). Moreover, P. capsici has a broad host range including several crops and weed species (Lamour et al., 2012). Disease control measures include crop rotation, cultural practices, application of fungicides, and the use of resistant cultivars (Café-Filho and Ristaino, 2008; Candole et al., 2010; Glosier et al., 2008). Chemical control is limited and P. capsici isolates resistant to systemic phenylamide fungicides have been identified (Café-Filho and Ristaino, 2008). The use of resistant cultivars is the most effective and viable control method with a low environmental impact.

Various resistant cultivars have been produced (Barksdale et al., 1984; Bosland, 2010; Guerrero-Moreno and Laborde, 1980; Kimble and Grogan, 1960; Pochard and Chambonnet, 1971), but these cultivars are not resistant at all locations (Oelke et al., 2003). Previous studies have determined factors that

Received for publication 15 June 2012. Accepted for publication 14 Aug. 2012. Claudia S. da Costa Ribeiro was supported by a doctoral fellowship from Embrapa.

A contribution of the New Mexico Agr. Expt. Sta., New Mexico State Univ., Las Cruces.

${ }^{1}$ Graduate Student, Researcher of Embrapa Vegetables, Brasilia, DF, Brazil.

${ }^{2}$ Regents Professor

${ }^{3}$ Corresponding author. E-mail: pbosland@nmsu.edu. affect the expression of resistance genotypes; e.g., plant age, P. capsici isolate origin, zoospore concentration, and inoculation method (Ortega and Espanol, 1983; Pochard and Chambonnet, 1971; Pochard et al., 1976; Reifschneider et al., 1986a). Disease ratings in pepper plants vary with $P$. capsici isolate, and very high inoculum concentrations of $P$. capsici can result in disease symptoms on resistant plants (Barksdale et al., 1984; Kim et al., 1989; Reifschneider et al., 1986a). In addition, breeding for Phytophthora resistance in Capsicum is difficult because the pathogen has different physiological races for the separate disease syndromes, i.e., root rot and foliar blight syndromes (Glosier et al., 2008; Oelke et al., 2003; Sy et al., 2008). Oelke et al. (2003) were the first authors to identify physiological races of $P$. capsici for phytophthora root rot and phytophthora foliar blight syndromes in pepper using a set of different cultivars of Capsicum annuum as host differentials. Phytophthora capsici is a heterothallic species with two mating types, and when isolates of different compatibility type (A1 and A2) are in close proximity, this increases the probability of sexual mating and formation of new physiological races (Erwin and Ribeiro, 1996; Lamour and Hausbeck, 2000; Sy et al., 2008).

Physiological races have been identified using cultivar differentials since 1919, when Stakman (1919) developed a scheme for race identification of Puccinia graminis f. sp. tritici, the causal agent of wheat rust. For physiological race identification, it is necessary that accessions used as differential hosts carry different race-specific resistance genes (Stakman, 1919). Sy et al. (2008) developed a population of $76 \mathrm{New}$ Mexico recombinant inbred lines (NMRILs) from hybridization between a highly Phytophthora resistant accession (Criollo de Morelos-334) and a susceptible commercial cultivar 
(Early Jalapeno) that was advanced by a single-seed-descent method until $\mathrm{F}_{7}$ generation. Using the NMRILs as host differential, 13 physiological races of $P$. capsici for the root rot disease syndrome were identified (Sy et al., 2008).

The objectives of this study were: 1) to compare the effectiveness of the New Mexico State University (NMSU) screening method for $P$. capsici root rot resistance with the screening method used at Embrapa Vegetables in Brazil; and 2) to attempt to characterize physiological races of $P$. capsici isolates from Brazil using a representative subset of the mentioned NMRILs.

\section{Materials and Methods}

\section{Expt. 1: Effect of screening method}

Plant materials. The $C$. annum accessions Criollo de Morelos-334 (CM-334) and CNPH-148, a Brazilian line with juvenile resistance selected from CM-334 (Reifschneider et al., 1986b), were used as resistant controls. 'Camelot', NMCA 10399, and the Brazilian cultivar Magda were used as susceptible controls. Seedlings were grown in planting trays composed of 72 cells divided into 18 four-celled containers (\#TOD 1804; T.O. Plastics, Clearwater, MN). Cells were filled with a commercial peatmoss-vermiculite soil mixture (Redi-earth plug and seedling mix; SunGro Horticulture, Bellevue, WA). Seeds were sown and the trays were placed on propagation pads in a greenhouse and the seedling medium temperature was kept at $28^{\circ} \mathrm{C}$ to improve seed germination. After germination, each cell was thinned to two seedlings that were inoculated when they reached the four- to six-true leaf stage.

Isolates AND INOCULUM PREPARATION. The $P$. capsici isolates were obtained from commercial production fields of pepper in Las Cruces, NM, and in Brazil. A total of four isolates were tested, PWB 24 (A2 mating type) and PWB 54 (A1) from the United States and Pcp106 (A1) and Pcp119 (A2) from Brazil. The isolates were maintained on water agar plates. Mycelial plugs $(0.5 \mathrm{~cm}$ in diameter) were taken from the water agar plates and transferred to V8 agar plates that were placed in an incubator at $28^{\circ} \mathrm{C}$ for a period of 4 to $8 \mathrm{~d}$. Once the V8 agar was covered with mycelium, the V8 agar was sliced into 12 pieces and transferred to $150 \times 15-\mathrm{mm}$ petri plates partially filled with distilled water. The dishes were incubated under fluorescent light for $2 \mathrm{~d}$ at $25{ }^{\circ} \mathrm{C}$, at which time abundant sporangia were produced on the V8 agar slices. To promote the release of zoospores, the water plate culture was placed in a refrigerator at $10{ }^{\circ} \mathrm{C}$ for $60 \mathrm{~min}$ and then moved to an incubator $\left(25^{\circ} \mathrm{C}\right)$ for $\approx 60 \mathrm{~min}$.

New Mexico State University screening method. The root rot screening protocol described by Bosland and Lindsey (1991) was followed. To summarize the method, each cell received $5 \mathrm{~mL}$ of the 2,000 zoospores/mL with a final concentration of 10,000 zoospores/cell. Plant trays with drainage holes were placed into trays filled with water and maintained in a flooded condition for $48 \mathrm{~h}$ on propagation pads to ensure a constant soil temperature of $28{ }^{\circ} \mathrm{C}$. Approximately $10 \mathrm{~d}$ after inoculation, when the susceptible control exhibits extreme root rot symptoms, plants were scored for resistance or susceptibility.

EMBRAPA SCREENING METHOD. Inoculum was adjusted with a hemacytometer to 30,000 zoospores $/ \mathrm{mL}$. Seedlings at the four- to six-true leaf stage were inoculated by placing $5 \mathrm{~mL}$ of zoospores/ cell with a final concentration of 150,000 zoospores/cell. Plant trays were flooded and maintained as described previously. Plants were scored for resistance or susceptibility $10 \mathrm{~d}$ after inoculation, when the susceptible control exhibited extreme root rot symptoms.

Disease SCORING. The plants were evaluated as resistant or susceptible based on a disease scoring described by Bosland and Lindsey (1991). Plants with no symptoms on the roots and vigorous growth $($ score $=0)$ and plants with only a slight browning of roots with no stunting or wilting ( $\operatorname{score}=1$ ) were considered resistant. Plants with a slight stunting and very small lesions on stems ( score $=3$ ); brown roots, small lesions on the stem, lower leaves wilted, stunted plants ( brown roots, large lesions on stems, girdling, whole plant wilted, and stunted (score $=7$ ) to death (score $=9$ ) were considered susceptible. Even numbers were used for intermediate symptoms.

EXPERIMENTAL DESIGN AND STATISTICAL ANALYSIS. The experimental unit consisted of a tray containing 15 four-packs, in which three of the four-packs (two plants/cell) represented one of the five accessions tested. All accessions were randomly distributed in the tray. The experimental design was a $2 \times 4 \times 5$ factorial (method $\times$ isolate $\times$ accession). The experiment was repeated twice. The data were analyzed using PROC GLM within SAS (Version 9.2 for Windows; SAS Institute, Cary, NC).

\section{Expt. 2: Physiological race characterization}

Plant materials. The isolates of $P$. capsici from Brazil were characterized using the same subset of 26 NMRILS used by Sy et al. (2008) to test for similarity in races or if novel races exist in Brazil. The C. annuum accession CM-334 was the resistant control and the bell pepper cultivar Camelot (Seminis Vegetable Seeds, St. Louis, MO) the susceptible control.

ISOLATES AND INOCULUM PREPARATION. A total of 20 isolates of $P$. capsici from different regions of Brazil and from different hosts were characterized (Table 1). Brazilian isolates were identified by morphology and sequencing of the ITS region by Embrapa plant pathologists. The inoculum was prepared based on the method of Bosland and Lindsey (1991).

INOCULATION METHOD AND DISEASE SCORING. Seedlings were inoculated at the four- to six-true leaf stage. Each cell received $5 \mathrm{~mL}$ of the prepared inoculum (10,000 zoospores/cell). Plants were scored for resistance or susceptibility $10 \mathrm{~d}$ after inoculation, when the susceptible control exhibited extreme root rot symptoms (Bosland and Lindsey, 1991).

EXPERIMENTAL DESIGN AND STATISTICAL ANALYSis. Trays containing 18 four-packs were used in the experiment. Each four-pack represented one NMRIL, and within a tray, each NMRIL was replicated four times and randomly distributed. The resistant control, CM-334, and the susceptible control, 'Camelot', were randomly placed in each tray. The screening of the 20 isolates was performed over time and all experiments were repeated at least two times.

The data were analyzed with SAS (Version 9.2 for Windows). The $\chi^{2}$ test of homogeneity was performed across the repetitions to determine if the data could be pooled. The $\chi^{2}$ test of homogeneity was also used for testing each NMRIL to the resistant control, CM-334, and the susceptible control, 'Camelot'. A NMRIL was considered resistant or susceptible if the $\chi^{2}$ test was not significant $(P>0.05)$ for a given comparison.

Mating TyPe Determination. To determine mating types, all isolates were individually paired with a known A1 (Brazilian 
Table 1. The origin, mating type, acquisition year, host, and disease syndrome for Phytophthora capsici isolates from Brazil.

\begin{tabular}{llcclc}
\hline Embrapa code & \multicolumn{1}{c}{ Origin $^{z}$} & Mating type & Isolation yr & Host & Disease syndrome \\
\hline Pcp42 & Minas Gerais & A1 & 2000 & Capsicum annum & Root rot \\
Pcp106 & Minas Gerais & A1 & 2005 & C. annuum & Root rot \\
Pcp113 & Goiás & A1 & 2007 & Capsicum baccatum & Fruit rot \\
Pcp114 & Goiás & A1 & 2007 & C. baccatum & Stem blight \\
Pcp116 & Goiás & A1 & 2007 & C. baccatum & Root rot \\
Pcp118 & Rio de Janeiro & A2 & 2008 & C. annuum & Root rot \\
Pcp119 & Minas Gerais & A2 & 2008 & C. annuum & Root rot \\
Pcp125 & Distrito Federal & A1 & 2008 & C. annuum & Root rot \\
Pcp126 & Distrito Federal & A1 & 2008 & Capsicum sp. & Root rot \\
Pcp127 & Minas Gerais & A1 & 2008 & C. annuum & Root rot \\
Pcp132 & Rio de Janeiro & A1 & 2008 & C. annuum & Root rot \\
Pcp133 & Rio de Janeiro & A1 & 2008 & C. annuum & Fruit rot \\
Pcp152 & Goiás & A1 & 2009 & C. annuum & Fruit rot \\
Pcbe19 & Espírito Santo & A1 & 2009 & Solanum melongena & Root rot \\
Pct26 & Goiás & A1 & 2006 & Solanum lycopersicum & Root rot \\
Pct33 & Goiás & A1 & 2007 & S. lycopersicum & Root rot \\
Pct38 & Goiás & A1 & 2007 & S. lycopersicum & Fruit rot \\
Pca26 & Rio de Janeiro & A1 & 2008 & Cucurbita pepo & Fruit rot \\
Pca33 & Minas Gerais & A2 & 2009 & Cucurbita maxima $\times$ Cucurbita moschata
\end{tabular}

${ }^{\mathrm{z}}$ State of Brazil.

${ }^{\mathrm{y}}$ Mating type $\mathrm{A} 1$ or $\mathrm{A} 2$ of $P$. capsici isolates.

isolate Pcp106) and a known A2 (PWB24) isolate. The isolates were placed $3 \mathrm{~cm}$ apart on clarified V8 culture media. Plates were incubated at $25^{\circ} \mathrm{C}$ for up to $7 \mathrm{~d}$ and then using a compound microscope were checked for the formation of oospore, the indication of a successful mating.

\section{Results}

EXPt. 1: Effect of SCREening Method. There were no significant differences between the two screening methods tested. Each screening method successfully distinguished between the known resistant and susceptible accessions. Furthermore, in both methods, the resistant accessions did not reveal any root rot symptoms and were scored as "1." Both CM-334 and CNPH-148 were consistently resistant. All $P$. capsici isolates tested caused $100 \%$ root rot symptoms, a rating of "9" on the three susceptible accessions, NMCA 10399, 'Camelot', and 'Magda'.

Expt. 2: Physiological race characterization. From the 20 isolates tested, nine isolates, Pcp119, Pcp127, Pcp132, Pcp133, Pcp152, Pca26, Pct26, Pct33, and Pct38, caused disease symptoms only on 'Camelot' (data not shown) and no disease symptoms on the 26 NMRILs tested. The remaining 11 isolates showed different levels of virulence based on the number of NMRILs infected. Isolates, Pca33 and Pca34, from japanese pumpkin (Cucurbita maxima $\times$ Cucurbita moschata) were the most virulent and caused root rot symptoms on all 26 NMRILs tested. When isolates from Capsicum were tested, Pcp42 was the most virulent causing root rot symptoms in 24 of 26 NMRILs (Table 2). The least virulent isolate in relation to the NMRILs was Pcp125 causing disease symptoms on only five of the 26 NMRILs (Table 2). The other isolates had virulence levels in between Pcp42 and Pcp125 (Table 2). The 26 NMRILs challenged with Brazilian isolates of $P$. capsici provided evidence for eight new races (Table 3 ).

\section{Discussion}

EFfect of SCREening Methods. Evaluation of pepper for resistance to $P$. capsici root rot varies in terms of inoculum type, inoculum concentration, and inoculation and screening method used by various workers. In several studies, zoospores were used for assessing resistance to phytophthora root rot at a concentration of $1 \times 10^{4}$ zoospores/plant (Bosland and Lindsey, 1991; Glosier et al., 2008), $5 \times 10^{4}$ zoospores/plant (Quirin et al., 2005), $1 \times 10^{5}$ zoospores/plant (Andres-Ares et al., 2005; Moran-Banuelos et al., 2010), $1.5 \times 10^{5}$ zoospores/plant (Reifschneider et al., 1986a), and $5 \times 10^{5}$ zoospores/plant (Ogundiwin et al., 2005).

In the two screening inoculation levels evaluated in this study, zoospores were used as inoculum because they are typically the infective propagules produced under natural conditions, and they are easier to quantify than mycelia pieces or oospores and to apply (Bosland and Lindsey, 1991). The inoculum concentration was the main difference between the two methods analyzed in this study. The Embrapa method has an inoculum concentration 15 -fold higher than that used in the NMSU's chile pepper breeding program screening method. The results indicate that a lower level of inoculum is as effective as the higher dosage. The lower inoculum level means that less resources are needed to screen for resistance to root rot. Embrapa's screening method did not affect the resistance of CM-334 nor CNPH-148. Moreover, all plants of the susceptible accessions 'Camelot', NMCA 10399, and 'Magda', showed disease symptoms when $P$. capsici isolates from Brazil were tested with NMSU's inoculation method with lower inoculum concentration than Embrapa's screening method. The results from this study indicate that the lower level of inoculum, i.e., 10,000 zoospores/cell, used in the NMSU's screening method is sufficient to determine resistance and susceptibility for the race characterization of Brazilian isolates. 
Table 2. Root rot disease reaction of 26 Capsicum annuum New Mexico recombinant inbred lines (NMRILs) to 11 isolates of Phytophthora capsici from Brazil.

\begin{tabular}{|c|c|c|c|c|c|c|c|c|c|c|c|}
\hline \multicolumn{12}{|c|}{ Brazilian isolates $^{z}$} \\
\hline Accession & Pca33 & Pca34 & Pcp42 & Pcp118 & Pcp113 & Pcp114 & Pcp116 & Pcp126 & Pcp106 & Pcbe19 & Pcp125 \\
\hline$\overline{\mathrm{CM}}-334^{\mathrm{y}}$ & $\mathrm{R}^{\mathrm{x}}$ & $\mathrm{R}$ & $\mathrm{R}$ & $\mathrm{R}$ & $\mathrm{R}$ & $\mathrm{R}$ & $\mathrm{R}$ & $\mathrm{R}$ & $\mathrm{R}$ & $\mathrm{R}$ & $\mathrm{R}$ \\
\hline NMRIL-C ${ }^{\mathrm{w}}$ & $S^{x}$ & S & $\mathrm{R}$ & $\mathrm{R}$ & $\mathrm{R}$ & $\mathrm{R}$ & $\mathrm{R}$ & $\mathrm{R}$ & $\mathrm{R}$ & $\mathrm{R}$ & $\mathrm{R}$ \\
\hline NMRIL-X & S & S & $\mathrm{R}$ & $\mathrm{R}$ & $\mathrm{R}$ & $\mathrm{R}$ & $\mathrm{R}$ & $\mathrm{R}$ & $\mathrm{R}$ & $\mathrm{R}$ & $\mathrm{R}$ \\
\hline NMRIL-F & S & S & S & $\mathrm{R}$ & $\mathrm{R}$ & $\mathrm{R}$ & $\mathrm{R}$ & $\mathrm{R}$ & $\mathrm{R}$ & $\mathrm{R}$ & $\mathrm{R}$ \\
\hline NMRIL-H & S & S & $\mathrm{S}$ & $\mathrm{R}$ & $\mathrm{R}$ & $\mathrm{R}$ & $\mathrm{R}$ & $\mathrm{R}$ & $\mathrm{R}$ & $\mathrm{R}$ & $\mathrm{R}$ \\
\hline NMRIL-O & S & $\mathrm{S}$ & $\mathrm{S}$ & $\mathrm{R}$ & $\mathrm{R}$ & $\mathrm{R}$ & $\mathrm{R}$ & $\mathrm{R}$ & $\mathrm{R}$ & $\mathrm{R}$ & $\mathrm{R}$ \\
\hline NMRIL-P & S & S & $\mathrm{S}$ & $\mathrm{R}$ & $\mathrm{R}$ & $\mathrm{R}$ & $\mathrm{R}$ & $\mathrm{R}$ & $\mathrm{R}$ & $\mathrm{R}$ & $\mathrm{R}$ \\
\hline NMRIL-Q & $\mathrm{S}$ & S & $\mathrm{S}$ & S & $\mathrm{R}$ & $\mathrm{R}$ & $\mathrm{R}$ & $\mathrm{R}$ & $\mathrm{R}$ & $\mathrm{R}$ & $\mathrm{R}$ \\
\hline NMRIL-K & S & S & S & S & $\mathrm{S}$ & $\mathrm{S}$ & S & $\mathrm{R}$ & $\mathrm{R}$ & $\mathrm{R}$ & $\mathrm{R}$ \\
\hline NMRIL-S & S & S & $\mathrm{S}$ & S & S & $\mathrm{S}$ & S & $\mathrm{R}$ & $\mathrm{R}$ & $\mathrm{R}$ & $\mathrm{R}$ \\
\hline NMRIL-T & S & S & $\mathrm{S}$ & $\mathrm{R}$ & $\mathrm{S}$ & $\mathrm{S}$ & S & $\mathrm{R}$ & $\mathrm{R}$ & $\mathrm{R}$ & $\mathrm{R}$ \\
\hline NMRIL-Z & S & S & S & S & S & $\mathrm{S}$ & S & $\mathrm{R}$ & $\mathrm{R}$ & $\mathrm{R}$ & $\mathrm{R}$ \\
\hline NMRIL-A & S & S & $\mathrm{S}$ & S & $\mathrm{S}$ & $\mathrm{S}$ & S & $\mathrm{S}$ & $\mathrm{R}$ & $\mathrm{R}$ & $\mathrm{R}$ \\
\hline NMRIL-B & $\mathrm{S}$ & $\mathrm{S}$ & $\mathrm{S}$ & $\mathrm{S}$ & $\mathrm{S}$ & $\mathrm{S}$ & $\mathrm{S}$ & $\mathrm{S}$ & $\mathrm{R}$ & $\mathrm{R}$ & $\mathrm{R}$ \\
\hline NMRIL-G & $\mathrm{S}$ & S & $\mathrm{S}$ & S & $\mathrm{S}$ & $\mathrm{S}$ & S & $\mathrm{S}$ & $\mathrm{R}$ & $\mathrm{R}$ & $\mathrm{R}$ \\
\hline NMRIL-L & $\mathrm{S}$ & $\mathrm{S}$ & S & S & $\mathrm{S}$ & $\mathrm{S}$ & S & $\mathrm{S}$ & $\mathrm{R}$ & $\mathrm{R}$ & $\mathrm{R}$ \\
\hline NMRIL-M & S & S & $\mathrm{S}$ & S & S & $\mathrm{S}$ & S & $\mathrm{S}$ & $\mathrm{R}$ & $\mathrm{R}$ & $\mathrm{R}$ \\
\hline NMRIL-AB & S & S & $\mathrm{S}$ & S & S & $\mathrm{S}$ & S & $\mathrm{S}$ & $\mathrm{R}$ & $\mathrm{R}$ & $\mathrm{R}$ \\
\hline NMRIL-J & $\mathrm{S}$ & S & S & S & $\mathrm{S}$ & $\mathrm{S}$ & S & S & $\mathrm{S}$ & $\mathrm{R}$ & $\mathrm{R}$ \\
\hline NMRIL-N & S & S & $\mathrm{S}$ & S & S & $\mathrm{S}$ & S & S & $\mathrm{R}$ & S & $\mathrm{R}$ \\
\hline NMRIL-E & S & S & S & S & S & $\mathrm{S}$ & S & S & $\mathrm{S}$ & S & $\mathrm{R}$ \\
\hline NMRIL-R & $\mathrm{S}$ & S & $\mathrm{S}$ & S & $\mathrm{S}$ & $\mathrm{S}$ & S & $\mathrm{S}$ & $\mathrm{S}$ & $\mathrm{S}$ & $\mathrm{R}$ \\
\hline NMRIL-D & $\mathrm{S}$ & $\mathrm{S}$ & $\mathrm{S}$ & $\mathrm{S}$ & $\mathrm{S}$ & $\mathrm{S}$ & $\mathrm{S}$ & S & $\mathrm{S}$ & $\mathrm{S}$ & $\mathrm{S}$ \\
\hline NMRIL-I & $\mathrm{S}$ & S & $\mathrm{S}$ & $\mathrm{S}$ & $\mathrm{S}$ & $\mathrm{S}$ & S & $\mathrm{S}$ & $\mathrm{S}$ & $\mathrm{S}$ & $\mathrm{S}$ \\
\hline NMRIL-V & S & S & $\mathrm{S}$ & S & $\mathrm{S}$ & $\mathrm{S}$ & S & $\mathrm{S}$ & $\mathrm{S}$ & $\mathrm{S}$ & $\mathrm{S}$ \\
\hline NMRIL-AA & $\mathrm{S}$ & S & $\mathrm{S}$ & $\mathrm{S}$ & $\mathrm{S}$ & $\mathrm{S}$ & S & $\mathrm{S}$ & $\mathrm{S}$ & $\mathrm{S}$ & $\mathrm{S}$ \\
\hline NMRIL-AC & S & S & $\mathrm{S}$ & S & $\mathrm{S}$ & $\mathrm{S}$ & S & $\mathrm{S}$ & $\mathrm{S}$ & S & $\mathrm{S}$ \\
\hline Camelot $^{\mathrm{v}}$ & S & S & $\mathrm{S}$ & $\mathrm{S}$ & $\mathrm{S}$ & $\mathrm{S}$ & $\mathrm{S}$ & $\mathrm{S}$ & $\mathrm{S}$ & $\mathrm{S}$ & $\mathrm{S}$ \\
\hline
\end{tabular}

${ }^{\mathrm{z}}$ Designation of $P$. capsici isolates from the Embrapa culture collection (Embrapa Vegetables, Brasilia, Brazil), ordered from most virulent to least virulent isolate.

${ }^{\mathrm{y}}$ Criollo de Morelos-334 accession used as the resistant control.

${ }^{\mathrm{x}} \mathrm{R}=$ resistant phenotype, rated 0 to 1 (no lesions on the roots); $\mathrm{S}=$ susceptible phenotype, ranging from 2 to 9 (lesions on the roots to death plants) (Bosland and Lindsey, 1991).

${ }^{\text {w}}$ Arranged from most resistant to least resistant.

visceptible control.

Table 3. Physiological race designation of the 11 isolates of Phytophthora capsici from Brazil based on nine Capsicum annuum New Mexico recombinant inbred lines (NMRILs) host differential.

\begin{tabular}{|c|c|c|c|c|c|c|c|c|}
\hline Brazilian isolate & Pcp $125^{z}$ & Pcbe19 & Pcp106 & Pcp126 & $\frac{\frac{P c p 113}{\operatorname{Pcp} 114}}{\operatorname{Pcp} 116}$ & Pcp118 & Pcp42 & $\frac{\text { Pca33 }}{\text { Pca34 }}$ \\
\hline Race designation & $14^{\mathrm{y}}$ & 15 & 16 & 17 & 18 & 19 & 20 & 21 \\
\hline NMRIL-A $^{x}$ & $\mathrm{R}^{\mathrm{w}}$ & $\mathrm{R}$ & $\mathrm{R}$ & $\mathrm{S}$ & $\mathrm{S}$ & $\mathrm{S}$ & $\mathrm{S}$ & $\mathrm{S}$ \\
\hline NMRIL-D & $\mathrm{S}^{\mathrm{w}}$ & S & S & S & S & S & S & S \\
\hline NMRIL-J & $\mathrm{R}$ & $\mathrm{R}$ & $\mathrm{S}$ & S & S & $\mathrm{S}$ & S & S \\
\hline NMRIL-K & $\mathrm{R}$ & $\mathrm{R}$ & $\mathrm{R}$ & $\mathrm{R}$ & S & $\mathrm{S}$ & S & S \\
\hline NMRIL-O & $\mathrm{R}$ & $\mathrm{R}$ & $\mathrm{R}$ & $\mathrm{R}$ & $\mathrm{R}$ & $\mathrm{R}$ & S & S \\
\hline NMRIL-N & $\mathrm{R}$ & $\mathrm{S}$ & $\mathrm{R}$ & S & S & $\mathrm{S}$ & S & S \\
\hline NMRIL-S & $\mathrm{R}$ & $\mathrm{R}$ & $\mathrm{R}$ & $\mathrm{R}$ & S & $\mathrm{S}$ & S & S \\
\hline NMRIL-T & $\mathrm{R}$ & $\mathrm{R}$ & $\mathrm{R}$ & $\mathrm{R}$ & S & $\mathrm{R}$ & S & S \\
\hline NMRIL-X & $\mathrm{R}$ & $\mathrm{R}$ & $\mathrm{R}$ & $\mathrm{R}$ & $\mathrm{R}$ & $\mathrm{R}$ & $\mathrm{R}$ & S \\
\hline
\end{tabular}

${ }^{\mathrm{z}}$ Designation of P. capsici isolates from the Embrapa culture collection (Embrapa Vegetable Crops, Brasilia, Brazil), arranged from least virulent to most virulent.

${ }^{y} \mathrm{New}$ race designation, ordered from race 14 to 21, following the phytophthora root rot race designation number used by Sy et al. (2008). ${ }^{x}$ NMRILs arranged in alphabetic order.

${ }^{\mathrm{w}} \mathrm{R}=$ resistant phenotype, rated 0 to 1 (no lesions on the roots); $\mathrm{S}=$ susceptible phenotype, ranging from 2 to 9 (lesions on the roots to death plants) (Bosland and Lindsey, 1991). 
Physiological race Characterization. Physiological race (sometimes shorten to "race") is a subdivision of a pathogen species that is distinguished from other members of the species by specialization for virulence on different cultivars of the same host species (Kirk et al., 2001). Oelke et al. (2003) demonstrated that physiological races exist within $P$. capsici based on distinct reactions of $C$. annuum cultivars. In a gene-for-gene interaction between a host and a pathogen, each gene of resistance in the host interacts with a corresponding gene for avirulence in the pathogen (Flor, 1971). The P. capsiciC. annuum spp. system works in a gene-for-gene basis and highly resistant cultivars may require several resistant genes to be functionally resistant in a grower's field (Sy et al., 2008). It is known that $P$. capsici isolate variability can be observed from one location to another, among different plants in the same local, and among different organs on the same plant (Glosier et al., 2008; Lamour et al., 2012; Walker and Bosland, 1999). Genetic variability among pathotypes can be generated through mutation or genetic recombination.

Recombinant inbred line populations have been successfully used as host differentials to identify physiological races of different plant pathogens; e.g., Phaseolus, Helianthus, Solanum, etc. (Miklas et al., 2000; Murphy, 2001; Tang et al., 2003; Tekeoglu et al., 2000; Yuanfu et al., 2009). Sy et al. (2008) used initially a subset of 26 NMRILs for characterizing isolates of $P$. capsici into physiological races. From this subset, eight NMRILs (NMRIL-A, NMRIL-B, NMRIL-F, NMRIL-G, NMRIL-H, NMRIL-N, NMRIL-X, and NMRIL-Z) were the minimal number of NMRILs capable of differentiating 16 isolates of $P$. capsici into 13 races (Sy et al., 2008).

The same subset of eight NMRILs selected by Sy et al. (2008) was not able to characterize all the Brazilian isolates of $P$. capsici tested into distinct races. Therefore, the larger subset of 26 NMRILs used by Sy et al. (2008) was used to characterize the 11 isolates of $P$. capsici from Brazil. When the results of the screening are compared with the races identified by Sy et al. (2008), eight novel physiological races were identified. From the 26 NMRILs tested, nine NMRILs were needed as the minimal number of NMRILs to distinguish among the eight novel races found in the Brazilian $P$. capsici populations.

Both Pca33 and Pca34, from japanese pumpkin fruit, were considered the same race (race 21 ) because they had the same disease response on the 26 NMRILs tested. It is important to note that they were collected together on the same farm in Minas Gerais state, Brazil. Likewise, the isolates Pcp113, Pcp114, and Pcp116, which are considered to be the same physiological race (race 18), were collected together on the same farm in Goiás state but from different plant parts of Capsicum baccatum plants. All 26 NMRILs tested showed similar disease responses when inoculated with these three isolates.

From the eight new races identified, three races (race16, race 20, and race 21) are from Minas Gerais state, two (races 14 and 17) are from Distrito Federal, one (race 19) is from Rio de Janeiro state, one (race 15) is from the Espírito Santo state, and one (race 18) is from Goiás state. These states represent the Capsicum-growing regions of Brazil. The most virulent races based on the pathogen's reaction to the NMRILs were found in Minas Gerais (races 20 and 21), Rio de Janeiro (race 19), and Goiás (race18). Minas Gerais and Goiás states are among the major producers of chile pepper and cucurbits in Brazil, and $P$. capsici has been one of the most destructive chile pepper pathogens in these states. In cucurbits, $P$. capsici affects mainly the fruit because they are in direct contact with the contaminated soil; however, leaves, roots, and stems are also affected (Lima, 2006). In North Carolina, significant production losses caused by $P$. capsici were observed in both pepper and cucurbit fields (Ristaino, 1990).

The results from this study showed cross-infectivity of solanaceous and cucurbitaceous hosts by $P$. capsici isolates as demonstrated in another study (Sanogo and Clary, 2006). Likewise, an isolate from the fruit of chile pepper can be highly virulent when inoculated on chile pepper roots. Tian and Babadoost (2004) evaluated the pathogenicity of $P$. capsici isolates from pumpkins on 45 species of herbaceous plants and concluded that cucurbits and pepper were the most susceptible hosts. The two races from Gama (Distrito Federal) had different levels of virulence; the most virulent (race 17) was isolated from chile pepper root, whereas the least virulent (race 14) was isolated from bell pepper root, indicating that intraspecific host differences do exist.

The three isolates from processing tomato (Solanum lycopersicum) tested in this study did not show any disease symptoms on the 26 NMRILs tested (data not shown). Likewise, some isolates from bell pepper were not pathogenic to the 26 NMRILs tested but were pathogenic to the susceptible control, 'Camelot'.

The NMRILs successfully identified novel races within the isolates of $P$. capsici from Brazil. These results provide a better understanding of the race-specific resistance needed to breed for durable Phytophthora-resistant pepper cultivars in Brazil. A viable approach to breeding for resistance is to introgression race-specific resistance genes (gene pyramiding) against $P$. capsici isolates for a specific local or region into elite pepper cultivars. Because of the gene-for-gene interaction, each NMRIL can only test for one resistant allele per locus. This means that the range of races in a production field needs to be known to develop a multiresistant cultivar.

\section{Literature Cited}

Amaral, J.F. 1952. Requeima do pimentão. O Biológico 18:160-161. Andres-Ares, J.L., A. Rivera-Martinez, and J. Fernandez-Paz. 2005. Resistance of pepper germplasm to Phytophthora capsici isolates collected in northwest Spain. Spanish J. Agr. Res. 3:429-436.

Barksdale, T.H., G.S. Papavizas, and S.A. Johnston. 1984. Resistance to foliar blight and crown rot of pepper caused by Phytophthora capsici. Plant Dis. 68:506-509.

Bosland, P.W. 2010. NuMex Vaquero jalapeno. HortScience 45:15521553.

Bosland, P.W. and D.L. Lindsey. 1991. A seedling screen for phytophthora root rot pepper, Capsicum annuum. Plant Dis. 75:1048-1050.

Café-Filho, A.C. and J.B. Ristaino. 2008. Fitness of isolates of Phytophthora capsici resistant to mefenoxam from squash and pepper fields in North Carolina. Plant Dis. 92:1439-1443.

Candole, B.L., P.J. Conner, and P. Ji. 2010. Screening Capsicum annuum accessions for resistance to six isolates of Phytophthora capsici. HortScience 45:254-259.

Erwin, D.C. and O.K. Ribeiro. 1996. Phytophthora, disease worldwide. Amer. Phytopathol. Soc., St. Paul, MN.

Flor, H.H. 1971. Current status of the gene-for-gene concept. Annu. Rev. Phytopathol. 9:275-296.

Glosier, B.R., E.A. Ogundiwin, G.S. Sidhu, D.R. Sischo, and J.P. Prince. 2008. A differential series of pepper (Capsicum annuum) lines delineates fourteen physiological races of Phytophthora capsici. Euphytica 162:23-30. 
Guerrero-Moreno, A. and J.A. Laborde. 1980. Current status of pepper breeding for resistance to Phytophthora capsici in Mexico. Synopses of the IVth Mtg. Capsicum Working Group of EUCARPIA. p. 52-56.

Kim, Y.J., B.K. Hwang, and K.W. Park. 1989. Expression of agerelated resistance in pepper plants infected with Phytophthora capsici. Plant Dis. 73:745-747.

Kimble, K.A. and R.G. Grogan. 1960. Resistance to phytophthora root rot in pepper. Plant Dis. Rptr. 44:872-873.

Kirk, P.M., P.F. Cannon, J.V. David, and J.A. Stalpers. 2001. Dictionary of the fungi. 9th Ed. CABI, Wallingford, UK.

Lamour, K.H. and M.K. Hausbeck. 2000. Mefenoxam insensitivity and sexual stage of Phytophthora capsici in Michigan cucurbit fields. Phytopathology 90:396-400.

Lamour, K.H., R. Stam, J. Jupe, and E. Huitema. 2012. The oomycete broad-host-range pathogen Phytophthora capsici. Mol. Plant Pathol. 13:329-337.

Lima, M.L.P. 2006. Caracterização fenotípica e molecular de Phytophthora capsici de hortaliças e expressão e prospecção de resistancia em Cucurbitacea and Solanaceae. PhD diss., Universidade de Brasilia, Brasília, Brazil.

Miklas, P.N., R. Delorme, V. Stone, M.J. Daly, J.R. Stavely, J.R. Steadman, M.J. Basset, and J.S. Beaver. 2000. Bacterial, fungal, and viral disease resistance loci mapped in a recombinant inbred common bean population ('Dorado'/XAN 176). J. Amer. Soc. Hort. Sci. 125: 476-481.

Moran-Banuelos, S.H., V.H. Aguilar-Ricon, T. Corona-Torres, and E. Zavaleta-Mejia. 2010. Resistencia a Phytophthora capsici Leo. de chiles nativos del sur de Puebla, Mexico. Revista Fitotecnia Mexicana 33:21-26.

Murphy, A. 2001. What are the NRBK selections? Potato Gene Resources Nwsl. 8:1-3.

Oelke, L.M., R. Steiner, and P.W. Bosland. 2003. Differentiation of race specific resistance to phytophthora root rot and foliar blight in Capsicum annuum. J. Amer. Soc. Hort. Sci. 128:213-218.

Ogundiwin, E.A., T.F. Berke, M. Massoudi, L.L. Black, G. Huestis, D. Choi, S. Lee, and J.P. Prince. 2005. Construction of 2 intraspecific linkage maps and identification of resistance QTLs for Phytophthora capsici root-rot and foliar blight diseases of pepper (Capsicum annuum L.). Genome 48:698-711.

Ortega, R.G. and C.P. Espanol. 1983. A hypothesis to work on pepper breeding for Phytophthora capsici resistance. Proc. Vth Mtg. EUCARPIA Capsicum Eggplant Working Group. p. 165-170.

Pochard, E. and D. Chambonnet. 1971. Methodes de selection du piment pour la resistance au Phytophthora capsici et au virus du concombre. Annali Facoltá Scienze Agraria della Universitá di Torino 7:270-281.
Pochard, E., M. Clerjeau, and M. Pitrat. 1976. La resistance du piment: Capsicum annuum a Phytophthora capsici Leon. 1. Mise en evidence d'une progressive induction de la resistance. Annales de l'Amélioration des Plantes 26:35-50.

Quirin, E.A., E.A. Ogundiwin, J.P. Prince, M. Mazourek, M.O. Briggs, T.S. Chlanda, K.T. Kim, M. Falise, B.C. Kang, and M.M. Jahn. 2005. Development of sequence characterized amplified region (SCAR) primers for the detection of Phyto.5.2, a major QTL for resistance to Phytophthora capsici Leon. in pepper. Theor. Appl. Genet. 110: 605-612.

Reifschneider, F.J.B., A.C. Cafe-Filho, and A.M. Rego. 1986a. Factors affecting expression of resistance in pepper (Capsicum annuum) to blight caused by Phytophthora capsici in screening trials. Plant Pathol. 35:451-456.

Reifschneider, F.J.B., A.C. Cafe-Filho, and A.M. Rego. 1986b. Reaction of pepper genotypes to blight, 1983. Biol. Cultural Tests 1:13. Ristaino, J.B. 1990. Intraspecific variation among isolates of Phytophthora capsici from pepper and cucurbit fields in North Carolina. Phytopathology 80:1253-1259.

Sanogo, S. and M. Clary. 2006. Occurrence of phytophthora blight on pumpkin in New Mexico. Plant Dis. 90:1110.

Stakman, E.C. 1919. New biologic forms Puccinia graminis. J. Agr. Res. 16:103-105.

Sy, O., R. Steiner, and P.W. Bosland. 2005. Inheritance of phytophthora stem blight resistance as compared to phytophthora root rot and phytophthora foliar blight resistance in Capsicum annuum L. J. Amer. Soc. Hort. Sci. 130:75-78.

Sy, O., R. Steiner, and P.W. Bosland. 2008. Recombinant inbred line differential identifies race-specific resistance to phytophthora root rot in Capsicum annuum. Phytopathology 98:867-870.

Tang, S., A. Heesacker, V.K. Kishore, A. Fernandez, E.S. Sadik, G. Cole, and S.J. Knapp. 2003. Genetic mapping of the $O r_{5}$ gene for resistance to Orobanche race E in sunflower. Crop Sci. 43:10211028.

Tekeoglu, M., A. Tullu, W.T. Kaiser, and F.J. Muehlbauer. 2000. Inheritance and linkage of two genes that confer resistance to fusarium wilt in chickpea. Crop Sci. 40:1247-1251.

Tian, D. and M. Babadoost. 2004. Host range of Phytophthora capsici from pumpkin and pathogenicity of the isolates. Plant Dis. 88:485489.

Walker, S. and P.W. Bosland. 1999. Inheritance of phytophthora root rot and foliar blight resistance in pepper. J. Amer. Soc. Hort. Sci. 124:14-18.

Yuanfu, J., J.W. Scott, D.J. Schuster, and D.P. Maxwell. 2009. Molecular mapping of $T y-4$, a new tomato yellow leaf curl virus resistance locus on chromosome 3 of tomato. J. Amer. Soc. Hort. Sci. 134:281-288. 